\title{
Recommended daily allowance-based contribution of household's own agricultural production to food and nutrition security in Karamoja sub-region of Uganda
}

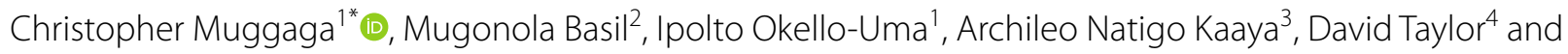
Duncan Ongeng ${ }^{1}$

\begin{abstract}
Background: In Uganda, agriculture is the main pathway for dietary intake among the households. Karamoja subregion, located in Northeastern part of Uganda is the most food insecure in the country. Although agriculture contributes greatly to Uganda's food systems, there is inadequate evidence for household energy and nutrient intake from agricultural production in the sub-region. Karamoja sub-region is typical because crop production has increasingly become part of the agricultural system in a largely semi-arid environment, predominantly occupied in pastoralism. Therefore, a cross-sectional study of 520 participants investigated the contribution of household's own agricultural production to dietary intake, seeking to answer whether or not own agricultural production translates into adequate energy and nutrient intake.
\end{abstract}

Results: Own food production did not meet energy and nutrient requirements, contributed disproportionately among the districts to household cumulated annual RDAs. This was reflected in the higher proportion of households in Moroto not attaining the cumulative annual RDA (energy: 100.0; protein 100.0; iron 86.5; and zinc 100.0\%) than in Abim (energy: 81.6; protein 53.3; iron 23.7; and zinc 59.9\%). Overall in Karamoja sub-region, the total energy and nutrients required by the household and supplied from their agricultural production were 15,589.7 $\pm 10,230.6$ and $4226.0 \pm 3980.1 \mathrm{kcal} /$ day for energy, $317.6 \pm 202.6$ and $154.4 \pm 153.7 \mathrm{~g} /$ day for proteins, $49.5 \pm 30.8$ and $50.2 \pm 47.6 \mathrm{mg} /$ day for iron, and $52.7 \pm 32.6$ and $25.4 \pm 24.5 \mathrm{mg} /$ day for zinc. Inter-household distribution of the absolute difference between energy and selected nutrients required by the household and that derived from own agricultural production showed deficits in household energy and nutrients needs. Further, polygamy, subsistence farming by spouse, lack of formal education by spouse positively predicted energy and nutrient supplied from own agricultural produce while lack of formal education negatively predicted energy nutrients supplied from agricultural produce. Increase in household size increased energy and nutrient required from agricultural production.

Conclusion: Own agricultural production contributes limitedly to household energy and nutrient needs in the subregion. There are great variations in the households' capacity to derive energy and nutrients from own agricultural

\footnotetext{
*Correspondence: c.muggaga@gu.ac.ug

1 Department of Food Science and Postharvest Technology, Faculty

of Agriculture and Environment, Gulu University, P.O. Box 166, Gulu, Uganda

Full list of author information is available at the end of the article
}

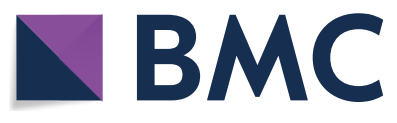

(c) The Author(s) 2022. Open Access This article is licensed under a Creative Commons Attribution 4.0 International License, which permits use, sharing, adaptation, distribution and reproduction in any medium or format, as long as you give appropriate credit to the original author(s) and the source, provide a link to the Creative Commons licence, and indicate if changes were made. The images or other third party material in this article are included in the article's Creative Commons licence, unless indicated otherwise in a credit line to the material. If material is not included in the article's Creative Commons licence and your intended use is not permitted by statutory regulation or exceeds the permitted use, you will need to obtain permission directly from the copyright holder. To view a copy of this licence, visit http://creativecommons.org/licenses/by/4.0/. The Creative Commons Public Domain Dedication waiver (http://creativeco mmons.org/publicdomain/zero/1.0/) applies to the data made available in this article, unless otherwise stated in a credit line to the data. 
produce in Karamoja sub-region. Polygamy, subsistence farming, education and household size predicted energy and nutrients required from and supplied by agricultural production.

Keywords: Household food security, Nutrient intake, Agricultural production, Agro-pastoralism, Karamoja sub-region, Semi-arid, Uganda

\section{Background}

Food and nutrition security is a basic human need and a central issue on both national and global agenda because of the role it plays human and economic development [1]. The 6th Report on the World Nutrition Situation by the "United Nations System Standing Committee on Nutrition" (UNSCN) in 2010 highlighted the crucial role of the agricultural sector in addressing food and nutrition challenges, emphasizing that nutrition-friendly, sustainable agricultural development was key to improving food and nutrition security [2]. Agricultural production is widely recognized as nutrition sensitive intervention for which its positive contribution are linked to diverse diets, women's empowerment, and better livelihoods [3, 4] and by implication, improved nutrition and health outcomes. For instance, agriculture increases production of diverse foods and availability of nutrient-rich crops, dietary diversity [5], improves per capita calorie intake, minimum meal frequencies, and significantly reduces stunting and underweight among children [6]. According to Sumelius et al. [7], agriculture either directly or indirectly, provided the livelihood for 70 percent of the world's poor. Similarly, it was reported that most of the rural poor depend greatly on agricultural activities, either through work on their own farms, or in agricultural wage employment from which they are able to obtain food resources for their households [8]. Higher productivity, especially in staple foods and on smallholder farms builds food security by increasing food availability and lowering the price of staple foods, thus improving access. In addition, smallholder farmers also grow cash crops, and the sales can provide more income to buy staple foods [9].

\section{The role family farming in addressing food security and dietary needs}

There is no consensus on the standard definition of family farming. Conceptually, in Sub-Saharan Africa, family farming is defined by governments, civil society and scholars as small-scale farming or smallholder faming (SSA) [10]. 'Small' may refer to the number of workers, capital invested, or amount of land worked but generally speaking, the Food and Agriculture Organization of the United Nations (FAO) adopted a 2-hectare (ha) threshold as a broad measure of a small farm (which is not inclusive of fishers and other small-scale food producers) (International Fund for Agricultural Development
(IFAD) and United Nations Environmental Programme [11] (UNEP). Other authors [12] reported that size of a family farm varies from 1 to 10,000 ha in Brazil. Majority of the households are smallholders [13, 14], particularly in developing countries. As such, family farms are gateways for household food consumption and income needs. They engage wider markets through diverse agricultural, pastoral and natural resource management activities on customary land using the labor of family members [10]. By implication, improvement in agricultural interventions in the developing countries should underscore family farming to increase opportunities for rural unemployment, promote inclusive economic growth, and combat household food insecurity and hunger $[12,13]$. Such efforts would, therefore, drive food consumption demand and lead to beneficial dietary changes [15]. This is of particular importance with regard to contribution of family farming towards achievement of Sustainable Development Goals (SDGs): Goal 1 which aims at ending poverty of all its forms (1.1, 1.2, 1.4); Goal which aims at Zero Hunger, improved security, nutrition and sustainable agriculture (2.1-2.5); and Goal 3 that aims at ensuring healthy lives and promoting well-being (3.1, 3.2, 3.4) SDG 3 [16]. Further, Berchina et al. [12] asserted that to increase food security locally and nationally, food production should be handled by smaller and more localized production. This also has high impact on households' diets especially when there is crop diversification [14]. Broadly speaking, the contribution of agricultural production to household food security has been established by several studies [1-9]. However, the available evidence has limited information on the extent to which household's own agricultural production supports their energy and nutrient needs. The intention of the current study is to fill this knowledge gap from the perspective of Karamoja sub-region in Uganda.

In Uganda, agriculture is the gateway for domestic food consumption [17], suggesting that agriculture is the main pathway for dietary intake among the households. A considerable proportion of the population cultivates food crops such as bananas, finger millet, sorghum, maize, cassava, sweet potatoes, beans and groundnuts [18-20], wheat, Irish Potatoes, rice, field peas, cow peas, pigeon peas, soya beans and simsim [21], sunflower, citrus and rice [22], and several vegetables. On the other hand, the most important cash crops are coffee, cotton, sugar and 
tea [18-20], cocoa, tobacco, and flowers and horticulture $[18,19]$. Of all these crops, ten crops that account for $90 \%$ of the plots under cultivation in Uganda: matooke (cooking type of banana), beans, cassava, sweet potatoes, coffee, groundnuts, maize, millet, sorghum and sesame [17]. Despite a variety of staples, food production and consumption is dominated by a few staple notably matooke, sweet potatoes, cassava, maize and beans and some of these foods produced for own consumption are also critical sources of household income [23].

Livestock production especially of cattle, sheep, goats, pigs, chicken have been on increase on account of steady efforts to control animal disease and improvement in livestock production systems as a result of routines livestock extension interventions [20]. In addition, apiculture and aquaculture have increasingly gained importance in Uganda [22]. Most of the contribution of the livestock sector to GDP is accounted for by pastoralists. Livestock production is the traditional economic activity in Karamoja sub-region. A joint report on food security status of Karamoja [24] indicated that $54 \%$ of the households in Karamoja sub-region owned livestock. Being predominantly a pastoral community, the numerous contribution of livestock to the inhabitants of Karamoja sub-region have been well documented including source of food, livelihoods, safety net, means of social exchange and form of investment $[25,26]$.

To boost food security, introduction of crop production in Karamoja sub-region as part of the intervention by both government and international agencies evolved over time in the recent years $[27,28]$. Cereals such as sorghum, millet and maize are cultivated during the rain season contributing to the household food availability and economy [26]. Other crops in the farming system in Karamoja sub-region include sunflower, beans, sweet potatoes, groundnuts, and simsim (sesame), cowpeas, green grams, pumpkin and famine reserve crops like cassava [29]. However, most parts of Karamoja sub-region have one planting season [30], such that unfavorable conditions during planting often result in food insecurity problems [29]. Crop production in Karamoja subregion is sensitive climate variability, particularly rainfall and temperature leading to fluctuations in yields. Even when the yield is more or less the same, erratic weather can stress the crops and lower the quality of the harvest, pushing the household to purchase out of home produced food [31]. Introduction of crop farming inevitably influences the dietary habits and food choices with potential ramifications on energy and nutrient intake the sub-region. However, there is inadequate evidence for household energy and nutrient intake from own agricultural production in the sub-region. Karamoja sub-region is typical in this case study because crop production has increasingly become part of the agricultural system in a largely semi-arid environment with predominantly pastoral community. The current study, therefore, investigated the contribution of households own agricultural production to dietary intake seeking, to answer whether or not own agricultural production translates to adequate energy and nutrient intake in a community whose livelihood is traditionally dependent on pastoral activity.

\section{Methods}

A cross-sectional study design employing quantitative methods was used in four of the nine districts of Karamoja sub-region. The participants consisted of pregnant women, lactating mothers and non-pregnant women who were willing to take part in the study. The reason for the choice of women as study participants was that women are also integral part of agricultural production system in Karamoja sub-region and most importantly, more reliable data could be obtained from them as they are the key players in harvesting, and preparation of foods in the households. The study participants were part of the previous study (Muggaga, 2021, unpublished) that established the sample size using a standard formula [32].

Hence, out of a total of 768 participants across the study districts, 520 participants whose information was complete were considered.

Multi-stage sampling was used reach the study participants. Accordingly, four districts were purposively selected on the basis of ethnic, livelihood zones, and geographical location. From each district, two sub counties were randomly selected by ballot. Therefore, the selected sub-counties and their respective districts were Alerek and Morulem in Abim district, Kathile and Sidok in Kabong district, Nadunget and Rupa in Moroto district, and Amudat and Loro in Amudat district. From each of the sub counties selected, two parishes were selected by systematic random sampling from which two villages were selected by systematic random sampling. The location of the study districts, sub-counties and parishes is indicated in Fig. 1. Finally, the participants were selected from each village with the assistance from village health teams/local council officials.

Data were collected with the help of trained research assistants who were resident and fluent in the local languages in the respective districts. The data were collected from October 2014 to June 2015 using a semi-structured questionnaire administered through face-to-face interview. The type of data collected included demographic characteristics (age, household size, gender, education level, family type and marital status), amount of household production of plant-based foods. Plant-based foods were used because it constitutes majority of the diets of Karamojong community (Muggaga, 2021, unpublished) 


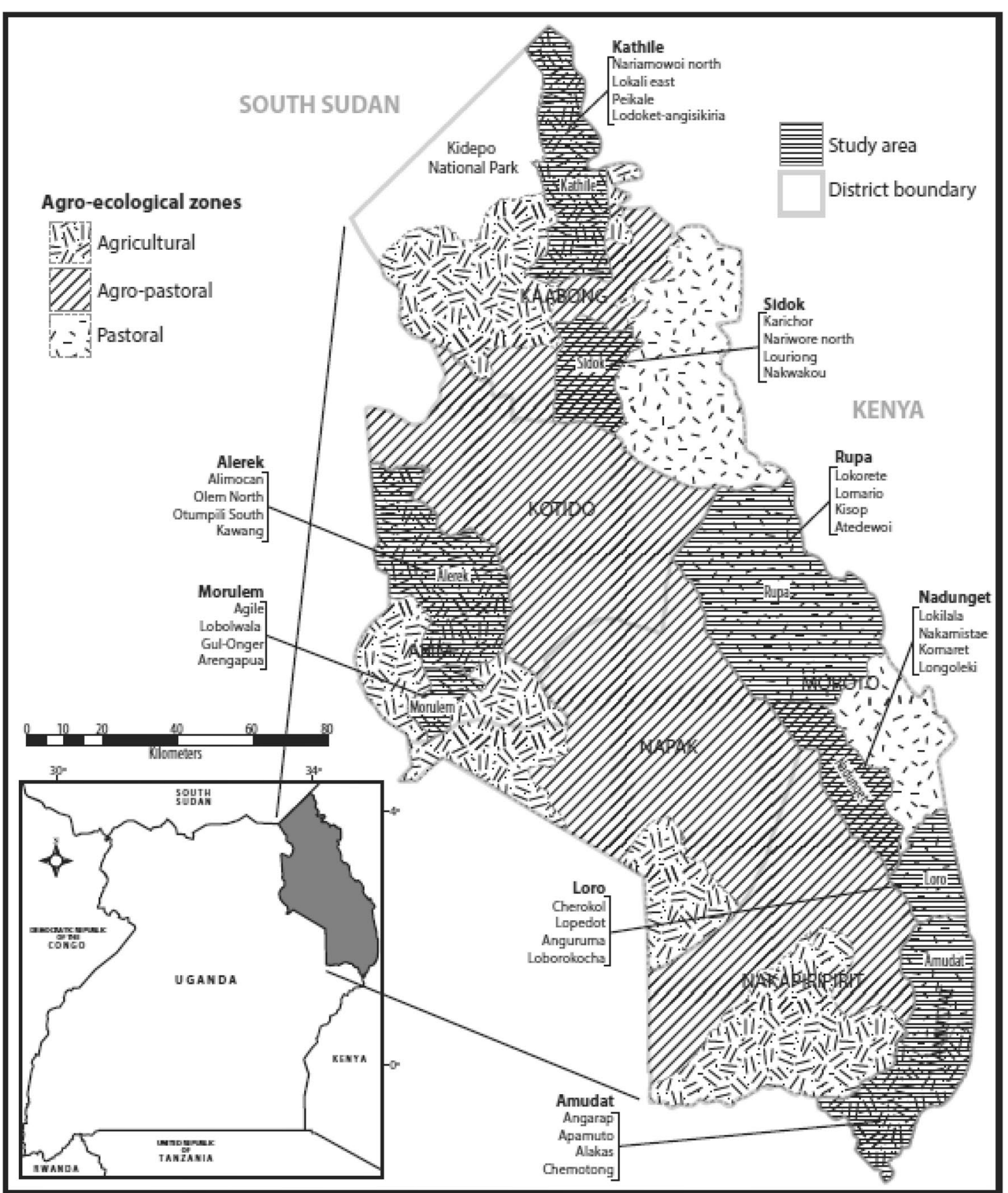

Fig. 1 The map of Karamoja sub-region indicating the study areas

and due to the some cultural restrictions on the consumption of most animal-based foods [33] to the exclusion of women and children who are also members of the households.

The amounts of food produced by each household were established in terms of counts, kilograms and accepted local units (such as trays, cans, bags, tins, basins, jags, etc.). All the quantities of food produced were standardized to kilograms. Total household energy and nutrient content from foods produced by the households were calculated using the food composition table of Harvest plus [34]. On the other hand, the total recommended daily allowances of the entire household was calculated using a summary tables of energy requirement [35] and 
dietary reference intake [36] taking into account the age, sex and/or physiological status (pregnancy, lactating and non pregnant) of the household members. The levels of household energy and nutrient requirements generated from the summary of the tables and dietary reference intake are indicated in Table 1.

The data were analyzed using descriptive statistics and presented as proportions, mean and standard deviations, and graphs. Proportion of the households that did not meet energy and nutrient requirements from agricultural produce segregated by district was computed. The energy and nutrients were calculated, analyzed and presented as mean energy and nutrients required by the households compared with energy and nutrients supplied by agricultural produce. For each household, absolute difference in energy and nutrients supplied from agricultural produce and corresponding requirements of the household was calculated on Microsoft Office Excel spread sheet and the patterns presented as graphs to reveal inter-household variations.
In addition, a linear regression was used to determine socio-economic and demographic predictors of energy and nutrient required from and supplied by own agricultural production. The regression model used is presented in Eq. 1:

$$
Y i=\beta 0+\beta 1 X 1+\beta 2 X 2+\cdots \beta n X n+\mu
$$

where:

$Y_{i}$ is the nutrition outcome variables: energy, proteins, iron, and zinc required by the household and supplied from the own agricultural produce. $\beta 0$ is the regression constant; $\beta$ is the regression coefficient; $X$ denotes a vector of control variables and they include age, marital status, family type and other household and contextual factors; $\mu$ is the random error term. The details of the control variable and the expected priori sign are presented in Table 2.

All the data were analysed using Microsoft Office Excel and IBM Statistical package for Social Science (SPSS) version 20.

Table 1 Dietary reference intakes for energy and nutrients

\begin{tabular}{|c|c|c|c|c|c|c|c|c|}
\hline \multirow[t]{2}{*}{ Category } & \multicolumn{2}{|c|}{ Energy (Kcal/d) } & \multicolumn{2}{|c|}{ Proteins (g/d) } & \multicolumn{2}{|c|}{ Iron (mg/day) } & \multicolumn{2}{|c|}{ Zinc (mg/d) } \\
\hline & Male & Female & Male & Female & Male & Female & Male & Female \\
\hline Children $0-5$ years & 1171.00 & 1076.00 & 13.03 & 13.03 & 4.67 & 4.67 & 3.00 & 3.00 \\
\hline Children 6-10 years & 1745.00 & 1625.00 & 26.50 & 26.50 & 5.00 & 4.90 & 5.50 & 5.50 \\
\hline Children $11-17$ years & 2629.00 & 2342.00 & 56.00 & 46.00 & 6.80 & 6.80 & 7.75 & 7.15 \\
\hline Adults $>18$ years & 2581.00 & 2103.00 & 56.00 & 71.00 & 6.00 & 8.03 & 7.75 & 6.80 \\
\hline Pregnant women & & 2103.00 & & 71.00 & & 22.33 & & 9.80 \\
\hline Lactating mothers & & 2103.00 & & 71.00 & & 6.67 & & 10.60 \\
\hline
\end{tabular}

Human energy requirements, Joint FAO/WHO/UNU Expert Consultation, Rome [35]; summary of tables: Dietary Reference Intakes-Estimated Average requirements [36]

Table 2 Control variables, description/measurement and the priori expected sign

\begin{tabular}{|c|c|c|c|}
\hline $\begin{array}{l}\text { Control } \\
\text { variable }\end{array}$ & Description & Variable coding/definition & $\begin{array}{l}\text { Expected } \\
\text { priori } \\
\text { sign }\end{array}$ \\
\hline$X_{1}$ & Age in completed years & $20-39$ years $=1,<20$ or $>40=0$ & + or - \\
\hline$x_{2}$ & Marital status & $\begin{array}{l}\text { Married }=1 \text {, not married, widowed, single, widowed, widower or } \\
\text { divorced }=0\end{array}$ & $+o r-$ \\
\hline$x_{3}$ & Family type & Polygamous $=1$, monogamous $=0$ & + or - \\
\hline$X_{4}$ & Occupation of the household head & $\begin{array}{l}\text { Subsistence farming }=1 \text {, trader, casual labourer, civil servant, (Agro) pastoral- } \\
\text { ist, gold mining, firewood sale and others }=0\end{array}$ & + or - \\
\hline$x_{5}$ & Occupation of Spouse (woman) in the household & $\begin{array}{l}\text { Subsistence farming }=1 \text {, trader, casual labourer, civil servant, (Agro) pastoral- } \\
\text { ist, gold mining, firewood sale and others }=0\end{array}$ & $+o r-$ \\
\hline$x_{6}$ & Education status of the Spouse (woman) & No formal education $=1$, Primary one-tertiary education $=0$ & + or - \\
\hline$x_{7}$ & Education status of household head & No formal education $=1$, Primary one-tertiary education $=0$ & + or - \\
\hline$x_{8}$ & Number of women married & Continuous data & +or - \\
\hline$x_{9}$ & Household size & Continuous data & + or - \\
\hline
\end{tabular}




\section{Results}

Socio-economic and demographic profile of the participants (Table 3) indicate that across districts, pregnant women constituted 30-37\%, lactating mothers 33-41\% while $28-33 \%$ were non pregnant women. Most women (49-53\%) were 20-29 years old followed by women $30-39$ years old (22-34\%). Women in their teenage (1519 years) and women 40-49 years of age accounted for $10-16 \%$ and $2-15 \%$, respectively. Most women (84-96\%) were married followed by women $(2-13 \%)$ who were living single life. Polygamous and monogamous types of families were the most common ranging from 30 to $63 \%$ and 12 to $56 \%$ respectively. Some families that were polygamous or monogamous were of extended type. Spouses $(68-96 \%)$ were occupied in subsistence farming more than their male counterparts (49-73\%) who are the heads of the households. Household heads engaged in diverse livelihood activities such as trading, civil service, paid casual labour, pastoralism, gold mining, and firewood sale compared to their spouses. As far as education is concerned, most of the household heads and spouses especially in Kaabong, Moroto and Amudat districts never attained any formal education. The greatest proportion of household heads and spouses attained primary followed by secondary level of education. Abim district had the highest proportion of household head and spouses who attained primary, secondary, and tertiary levels of education, which is the opposite case in Amudat district. Most members of the household were adults (17-26\%) followed by children $0-5$ years old (10$15 \%)$, children $6-10$ years old $(10-14 \%)$ and children 11-17 years old $(6-10 \%)$ in order of decreasing magnitude. Overall, the proportion of the males and females in the household was approximately equal across all the districts.

The proportion of households that did not meet RDAs for energy and nutrients from their own agricultural production is presented in Table 4. According to this table, the proportion of households that did not meet energy and nutrient requirements were generally high across all the districts. The highest value was observed in Moroto district (86-100\%) followed by Amudat district (7797\%), Kaabong district (53-95\%) and lastly Abim district (23-81\%).

The average amounts of energy and nutrients required by the household and supplied by from agricultural production are presented in Table 5. Generally, the average energy and nutrients obtained from agricultural production was low in all the districts. The amount of energy and nutrients required by the household and that supplied from own agricultural production varied according to the district of abode. Abim district had the highest amount of average energy and nutrients supplied from agricultural production. Overall, in Karamoja subregion, the energy and nutrients required by the household and supplied from agricultural production were $15,589.7 \pm 10,230.6$ and $4226.0 \pm 3980.1 \mathrm{kcal} /$ day for energy, $317.6 \pm 202.6$ and $154.4 \pm 153.7 \mathrm{~g} /$ day for proteins, $49.5 \pm 30.8$ and $50.2 \pm 47.6 \mathrm{mg} /$ day for iron, and $52.7 \pm 32.6$ and $25.4 \pm 24.5 \mathrm{mg} /$ day for zinc.

Inter-household distribution of energy and selected nutrients derived from own agricultural production is presented in Figs. 2, 3, 4, 5. In these figures, all the patterns below zero indicate deficits in household energy and nutrients. Generally, the pattern indicates that own agricultural production varies from household to household, one district to another and from energy/nutrient to energy/nutrient. Energy supplied from agricultural production was not sufficient to meet the requirements of households as most of the trends lie below zero (Fig. 2). As far as protein is concerned (Fig. 3), some households in Abim, Kaabong and Amudat districts were able to meet daily requirements from agricultural production. Some households in all the districts met requirements for iron from agricultural production (Fig. 4). With exception of Moroto district, some households in Abim, Kaabong and Amudat districts were able to meet their zinc requirements from agricultural production (Fig. 5).

A linear regression of socio-economic and demographic factors with energy and nutrients (Table 6) indicate that being polygamous significantly increased iron supplied $(\beta: 0.112 ; p<0.05)$ from agricultural production. Subsistence farming by spouse significantly increased energy and nutrients supplied $(\beta: 0.139-0.158 ; p<0.05)$, and energy required $(\beta: 0.139 ; p<0.05)$ by the households while lack of education (non-formal education) significantly reduced energy and nutrient supplied $(\beta: 0.279$ $0.333 ; p<0.05)$ and energy required $(\beta: 0.302 ; p<0.05)$ by the households from own agricultural production. On the other hand, increase in household size significantly increased household requirement $(\beta: 0.098-0.116$; $p<0.05)$ for proteins, iron and zinc from own agricultural production.

\section{Discussion}

Karamoja sub-region exhibits diverse socio-economic and demographic characteristics depending on location, although similar patterns exist in certain characteristics such as physiological status, sex, education level, marital status, age, and household size (Table 3).

Farming is the primary livelihood occupation of women more than the male counterparts in Karamoja sub-region. This is consistent with a study [37] which reported that women were key players in domestic chores within the household while simultaneously generating significant household income in agriculture, petty trade in poultry 
Table 3 Proportion of households with various socioeconomic and demographic characteristics segregated by district

\begin{tabular}{|c|c|c|c|c|}
\hline \multirow[t]{2}{*}{ Socioeconomic and demographic category } & \multicolumn{4}{|c|}{ District } \\
\hline & Abim & Kaabong & Moroto & Amutat \\
\hline \multicolumn{5}{|l|}{ Physiological status } \\
\hline Pregnant & 34.9 & 36.8 & 34.6 & 30.4 \\
\hline Lactating & 36.2 & 36.3 & 32.7 & 41.3 \\
\hline Non pregnant & 28.9 & 26.9 & 32.7 & 28.3 \\
\hline \multicolumn{5}{|l|}{ Age } \\
\hline 15-19 years & 15.1 & 9.6 & 13.4 & 15.7 \\
\hline 20-29 years & 48.7 & 52.7 & 49.0 & 52.8 \\
\hline 30-39 years & 34.2 & 35.5 & 22.1 & 23.6 \\
\hline 40-49 years & 2.0 & 5.3 & 15.4 & 7.9 \\
\hline \multicolumn{5}{|l|}{ Marital status } \\
\hline Married & 93.4 & 92.4 & 83.7 & 95.5 \\
\hline Single & 2.0 & 7.6 & 12.5 & 4.5 \\
\hline Widowed & 3.3 & & 3.8 & \\
\hline Widower & 0.7 & & & \\
\hline Divorced & 0.7 & & & \\
\hline \multicolumn{5}{|l|}{ Family type } \\
\hline Polygamous family & 62.7 & 36.3 & 30.0 & 42.4 \\
\hline Monogamous family & 12.0 & 55.6 & 48.9 & 50.6 \\
\hline Monogamous extended family & 16.0 & 1.3 & 7.8 & \\
\hline Polygamous extended family & 9.3 & 6.9 & 13.3 & 5.9 \\
\hline \multicolumn{5}{|l|}{ Occupation of household head } \\
\hline Subsistence farmer/gardener & 58.9 & 66.5 & 72.7 & 48.9 \\
\hline Trader/seller & 3.3 & 0.6 & 4.5 & 11.4 \\
\hline Casual labourer & 0.7 & 0.6 & 6.1 & \\
\hline Civil servant & 11.9 & 10.2 & 6.1 & 2.3 \\
\hline Pastoralist & & 0.6 & 1.5 & 31.8 \\
\hline Agropastoralist & & & 3.0 & \\
\hline Gold mining & & 1.2 & 1.5 & 1.1 \\
\hline Fire wood sale & & 1.2 & 1.5 & \\
\hline Others & 19.9 & 19.2 & 3.0 & \\
\hline \multicolumn{5}{|l|}{ Occupation of spouse } \\
\hline Farmer/gardener & 96.1 & 81.4 & 68.4 & 90.8 \\
\hline Trader/seller & 2.6 & 0.7 & 1.3 & 4.6 \\
\hline Casual labourer & & & 5.1 & 1.1 \\
\hline \multicolumn{5}{|l|}{ Civil servant } \\
\hline Pastoralist & & & 1.3 & \\
\hline \multicolumn{5}{|l|}{ Agropastoralist } \\
\hline Gold mining & & 0.7 & 2.5 & 1.1 \\
\hline Fire wood sale & & 4.3 & 7.6 & \\
\hline Others & 1.3 & 12.9 & 13.9 & 2.3 \\
\hline \multicolumn{5}{|l|}{ Education of household head } \\
\hline No formal education/school & 8.6 & 51.2 & 89.1 & 92.0 \\
\hline Lower primary education (P1-P4) & 3.3 & 20.7 & 1.0 & 2.3 \\
\hline Upper primary education (P5-P7) & 37.5 & 15.9 & 4.0 & 2.3 \\
\hline O level incomplete (<4 Years) & 15.8 & 6.7 & 3.0 & 1.1 \\
\hline O level complete (Sat UCE) & 17.1 & 3.7 & 3.0 & 1.1 \\
\hline A level complete (Sat UACE) & 7.9 & & & \\
\hline Vocational training & 0.7 & & & \\
\hline
\end{tabular}


Table 3 (continued)

\begin{tabular}{|c|c|c|c|c|c|c|c|c|}
\hline \multirow{2}{*}{\multicolumn{3}{|c|}{ Socioeconomic and demographic category }} & \multicolumn{6}{|c|}{ District } \\
\hline & & & \multicolumn{2}{|c|}{ Abim } & Kaabong & \multicolumn{2}{|c|}{ Moroto } & Amutat \\
\hline \multicolumn{3}{|l|}{ Tertiary training } & 9.2 & & 1.8 & & & 1.1 \\
\hline \multicolumn{9}{|l|}{ Education of spouse } \\
\hline \multicolumn{3}{|c|}{ No formal education/school } & 24.3 & & 65.5 & \multicolumn{2}{|c|}{86.3} & 94.3 \\
\hline \multicolumn{3}{|c|}{ Lower primary education (P1-P4) } & 16.4 & & 29.1 & \multicolumn{2}{|c|}{4.9} & 3.4 \\
\hline \multicolumn{3}{|c|}{ Upper primary education (P5-P7) } & 41.4 & & 4.2 & \multicolumn{2}{|c|}{6.9} & 2.3 \\
\hline \multicolumn{3}{|c|}{ O level incomplete (<4 Years) } & 11.8 & & 0.6 & \multicolumn{2}{|c|}{2.0} & \\
\hline \multicolumn{3}{|c|}{ O level complete (Sat UCE) } & 5.3 & & 0.6 & & & \\
\hline \multicolumn{3}{|c|}{ A level complete (Sat UACE) } & 0.7 & & & & & \\
\hline \multirow[t]{2}{*}{ Household size } & \multicolumn{2}{|c|}{$\operatorname{Abim}(n=1001)$} & \multicolumn{2}{|c|}{ Kaabong $(n=1581)$} & \multicolumn{2}{|c|}{ Moroto $(n=854)$} & \multicolumn{2}{|c|}{ Amudat $(n=750)$} \\
\hline & Male & Female & Male & Female & Male & Female & Male & Female \\
\hline Adults $>18$ & 17.6 & 20.2 & 18.8 & 20.6 & 21.4 & 25.9 & 17.0 & 18.1 \\
\hline Children 11-17 Yrs & 7.4 & 7.3 & 8.3 & 9.5 & 5.5 & 7.5 & 8.0 & 5.9 \\
\hline Children (6-10 years) & 11.0 & 10.9 & 11.4 & 11.5 & 9.7 & 9.5 & 13.6 & 9.9 \\
\hline Children $0-5$ Years & 13.3 & 12.4 & 10.0 & 10.0 & 11.6 & 8.9 & 12.5 & 15.0 \\
\hline Total & 49.3 & 50.7 & 48.5 & 51.5 & 48.2 & 51.8 & 51.1 & 48.9 \\
\hline
\end{tabular}

Values in the table are percentages; $\mathrm{n}$ is the total number of the household members per district

Table 4 Proportion of households that fall below RDA on the basis of contribution from agricultural produce segregated by district

\begin{tabular}{lllll}
\hline $\begin{array}{l}\text { Energy } \\
\text { and } \\
\text { nutrients }\end{array}$ & \multicolumn{4}{l}{ Proportion of Households by District } \\
\cline { 2 - 5 } & $\begin{array}{l}\text { Abim } \\
\text { District } \\
(\boldsymbol{n}=\mathbf{1 5 2})\end{array}$ & $\begin{array}{l}\text { Kaabong } \\
\text { District } \\
(\boldsymbol{n}=\mathbf{1 7 1})\end{array}$ & $\begin{array}{l}\text { Moroto } \\
\text { District } \\
(\boldsymbol{n}=\mathbf{1 0 4})\end{array}$ & $\begin{array}{l}\text { Amudat } \\
\text { District } \\
(\boldsymbol{n}=\mathbf{9 3})\end{array}$ \\
\hline Energy & 81.579 & 95.906 & 100.000 & 97.849 \\
Proteins & 53.289 & 81.871 & 100.000 & 92.473 \\
Iron & 23.684 & 53.216 & 86.538 & 77.419 \\
Zinc & 59.868 & 82.456 & 100.000 & 87.097 \\
\hline
\end{tabular}

and food products, wage labor, and mining. Similar studies [38-40] also attest to the major roles women play in agriculture. The low involvement of males in agriculture could be attributed to their involvement in pastoralism, a role traditionally ascribed to males. On the other hand, although the involvement of household members in other livelihood activities such as casual labour, trade, gold mining, firewood sale, etc. (Table 3) is a good risk management strategy towards achieving food and nutrition security, it can reduce their time and concentration on agricultural activities. The households are also characterized by poor education status as results indicated high proportions of household heads and spouses who did not attend any formal education and by implication cannot read and write (Table 3). A study [41] revealed that low levels of education in a community could lead to an opportunity cost associated with low labour cost, which is expected to increase production levels lowing to limited employment opportunities outside agriculture. This paradox should be an important constraint for

Table 5 Mean energy and nutrients required by the households compared with energy and nutrients supplied by agricultural produce

\begin{tabular}{lllllllll}
\hline District & \multicolumn{7}{l}{ Mean energy and nutrients } \\
\cline { 2 - 9 } & Energy $^{\mathbf{1}}(\mathbf{K c a l} / \mathbf{d})$ & Energy $^{\mathbf{2}}(\mathbf{K c a l} / \mathbf{d})$ & Protein $^{\mathbf{1}}(\mathbf{g} / \mathbf{d})$ & Protein $^{\mathbf{2}}(\mathbf{g} / \mathbf{d})$ & Iron $^{\mathbf{1}}(\mathbf{m g} / \mathbf{d})$ & Iron $^{\mathbf{2}}(\mathbf{m g} / \mathbf{d})$ & Zinc $^{\mathbf{1}}(\mathbf{m g} / \mathbf{d})$ & Zinc $^{\mathbf{2}}(\mathbf{m g} / \mathbf{d})$ \\
\hline Abim $(n=152)$ & $12,518.5 \pm 6070.1$ & $6643.8 \pm 4975.9$ & $255.5 \pm 119.1$ & $259.7 \pm 198.3$ & $40.2 \pm 19.5$ & $85.1 \pm 59.2$ & $42.9 \pm 19.7$ & $41.3 \pm 31.2$ \\
Kaabong $(n=171)$ & $18,193.5 \pm 12,856.1$ & $4639.8 \pm 3115.1$ & $365.2 \pm 250.4$ & $160.4 \pm 111.3$ & $56.6 \pm 38.0$ & $51.4 \pm 33.8$ & $61.2 \pm 41.2$ & $26.4 \pm 18.4$ \\
Moroto $(n=104)$ & $16,203.7 \pm 9843.8$ & $1493.8 \pm 1597.9$ & $328.7 \pm 190.2$ & $55.0 \pm 55.7$ & $51.1 \pm 29.8$ & $19.4 \pm 19.9$ & $55.0 \pm 31.7$ & $8.7 \pm 9.0$ \\
Amudat $(n=93)$ & $15,134.9 \pm 9341.0$ & $2568.6 \pm 2597.4$ & $319.4 \pm 202.7$ & $82.3 \pm 87.0$ & $49.6 \pm 28.5$ & $25.3 \pm 27.4$ & $50.8 \pm 28.2$ & $16.2 \pm 16.5$ \\
Overall $(N=520)$ & $15,589.7 \pm 10,230.6$ & $4226.0 \pm 3980.1$ & $317.6 \pm 202.6$ & $154.4 \pm 153.7$ & $49.5 \pm 30.8$ & $50.2 \pm 47.6$ & $52.7 \pm 32.6$ & $25.4 \pm 24.5$ \\
\hline
\end{tabular}

\footnotetext{
${ }^{1}$ Total household energy and nutrients required; ${ }^{2}$ total household energy and nutrients supplied through agricultural production
} 


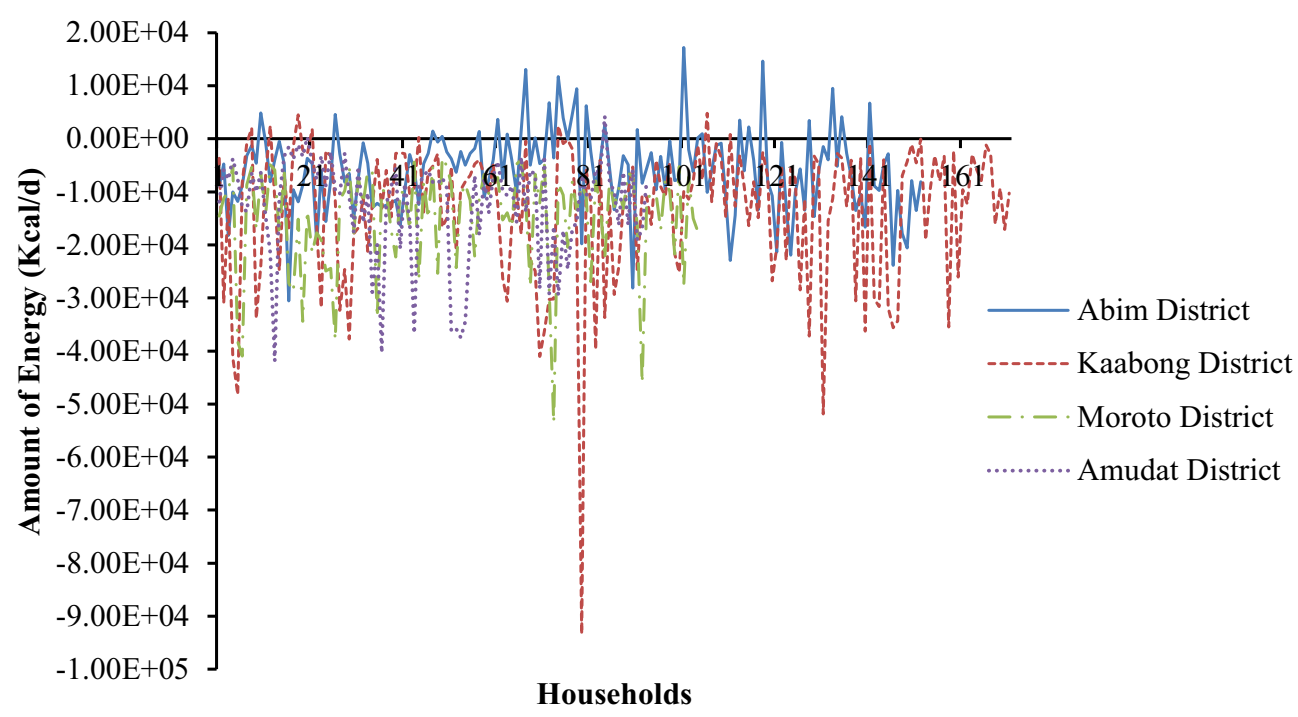

Fig. 2 Absolute difference between household energy supplied by agricultural production and requirement segregated by district

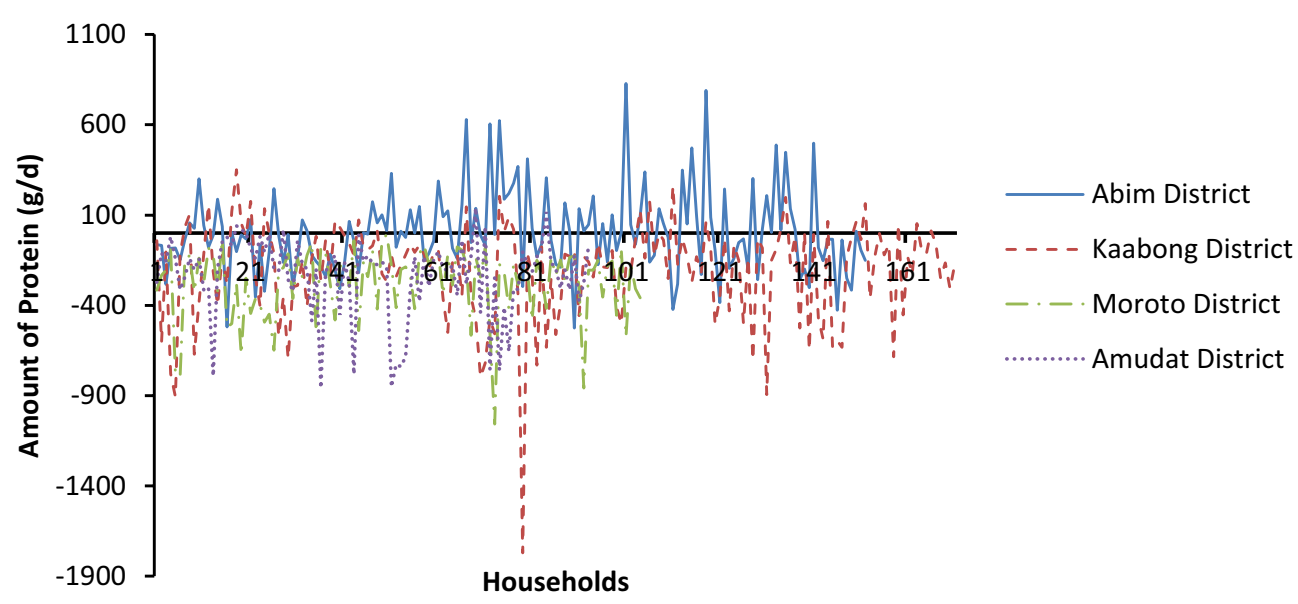

Fig. 3 Absolute difference between household protein supplied by agricultural production and requirement segregated by district

government and development partners because previous studies [42-44] suggest challenges in uptake of interventions in generally illiterate communities in an attempt to improve agricultural output.

Agricultural production is one of the critical gateways to achieve food and nutrition security. According to DFID [45] agriculture as one of the nutrition sensitive interventions has the potential to drive improved nutritional outcomes in many ways. For instance, it is a source of food and nutrients, a source of income, has effects on food prices, affects the environment in which people live and influences women's time for taking care of very young children and their power in decision making [45]. As source of food, agricultural produce by the farmers is used for their own household food consumption [46]. In Karamoja sub-region, agricultural production is rainfed [47] and greatly affected by unfavorable climatic conditions $[28,48]$, ultimately affecting household food availability and consequently nutrition security. This is reflected in the high proportion of households across district that were unable to meet energy and nutrient requirement (Table 4) and the average energy and nutrients supplied from agricultural produce falling far below the household requirements (Table 5). It is not surprising that the contribution of own agricultural production to household energy and nutrient requirement was the highest in Abim because the district is located in the agricultural zone of the sub-region [49-51] that receives 


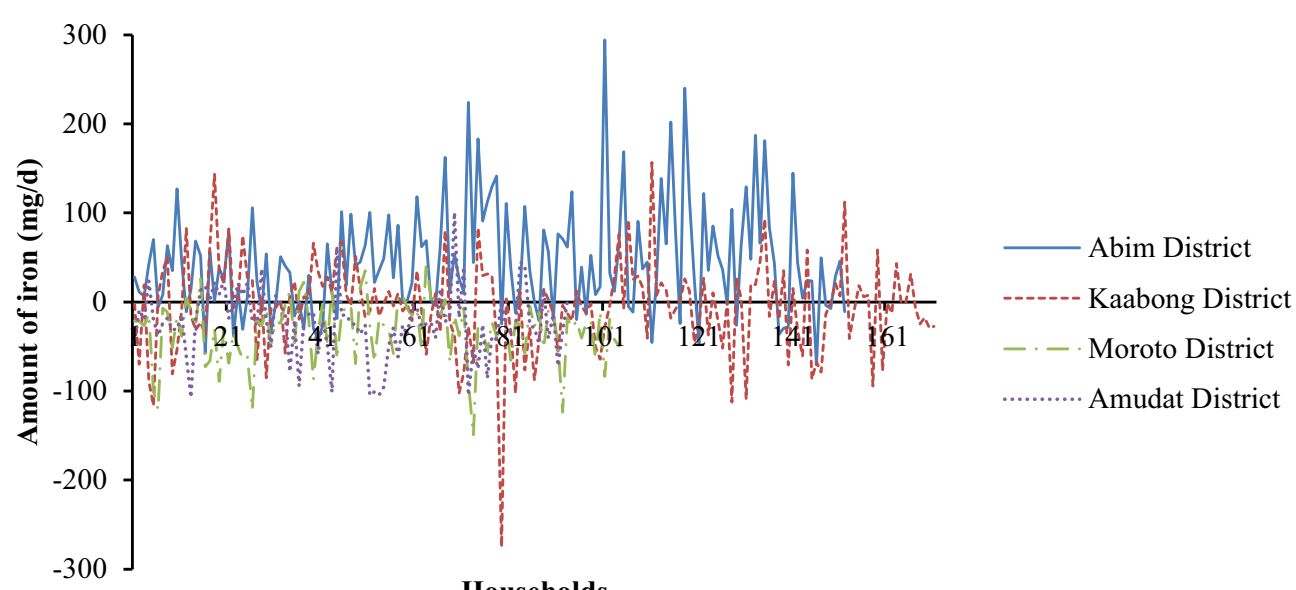

Households

Fig. 4 Absolute difference between household iron supplied by agricultural production and requirement segregated by district

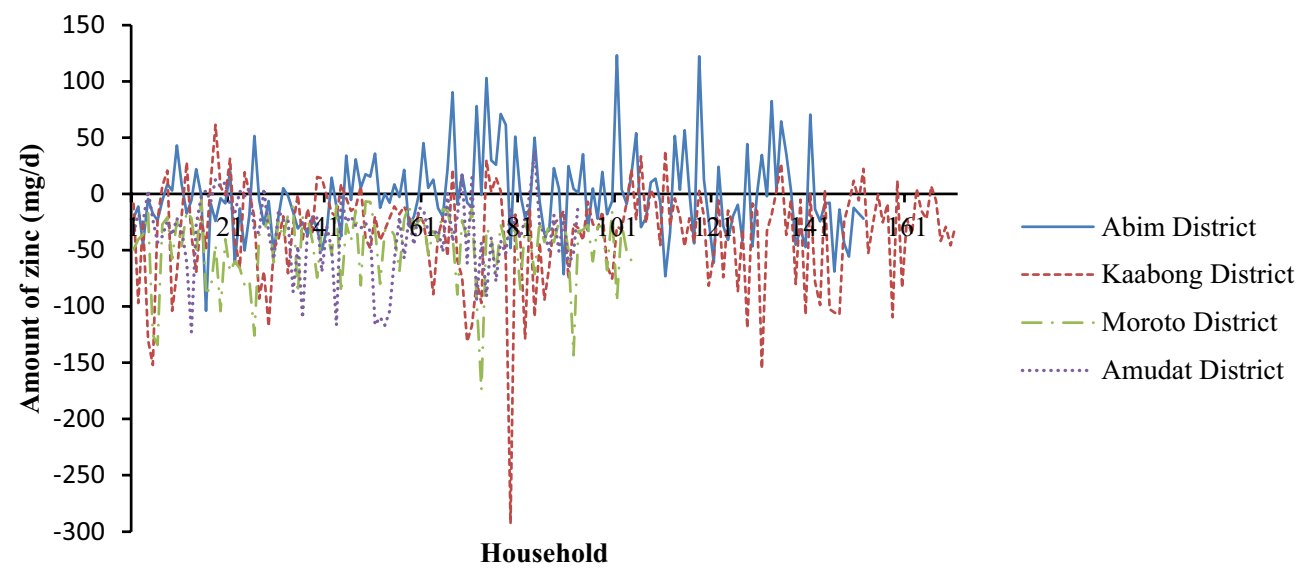

Fig. 5 Absolute difference between household zinc supplied by agricultural production and requirement segregated by district

Table 6 Socio-economic and demographic predictors of energy and nutrient required and supplied from own agricultural production

\begin{tabular}{|c|c|c|c|c|c|c|c|c|}
\hline \multirow[t]{2}{*}{ Predictors } & \multicolumn{2}{|l|}{ Energy } & \multicolumn{2}{|l|}{ Protein } & \multicolumn{2}{|l|}{ Iron } & \multicolumn{2}{|l|}{ Zinc } \\
\hline & Required & Supplied & Required & Supplied & Required & Supplied & Required & Supplied \\
\hline Age (20 to 39 years) & -0.002 & -0.001 & -0.046 & -0.002 & -0.014 & -0.006 & -0.029 & -0.003 \\
\hline Marital Status & -0.019 & -0.005 & -0.042 & -0.019 & -0.062 & -0.017 & -0.046 & -0.003 \\
\hline Family type (polygamous) & 0.093 & 0.103 & -0.044 & 0.093 & -0.035 & $0.112^{*}$ & -0.038 & 0.098 \\
\hline Occupation of household head (Subsistence farming) & -0.08 & -0.065 & 0.071 & -0.08 & 0.078 & -0.088 & 0.077 & -0.087 \\
\hline Occupation of spouse (Subsistence farming) & $0.139 *$ & $0.152^{*}$ & 0.078 & $0.139 *$ & 0.055 & $0.136^{*}$ & 0.063 & $0.158^{*}$ \\
\hline Education of Spouse & -0.033 & -0.015 & $0.116^{*}$ & -0.033 & 0.101 & -0.03 & $0.116^{*}$ & -0.026 \\
\hline Education of household head (No Formal education) & $-0.302^{*}$ & $-0.287^{*}$ & 0.011 & $-0.302^{*}$ & 0.005 & $-0.333^{*}$ & 0.001 & $-0.279 *$ \\
\hline No. women married & 0.021 & 0.016 & 0.076 & 0.021 & 0.084 & 0.047 & 0.074 & 0.014 \\
\hline Household size & 0.029 & 0.045 & $0.098^{*}$ & 0.029 & $0.116^{*}$ & 0.029 & $0.111^{*}$ & 0.045 \\
\hline
\end{tabular}

Standardized Coefficients; ${ }^{*}$ coefficients are significant at $5 \%$ for the predictor; household size, occupation $(1=$ subsistence farming; $0=$ otherwise) age $(1=20$ to 39 years; $0=$ otherwise), education ( $1=$ no formal education; $0=$ otherwise), family type $(1=$ polygamous family; $0=$ otherwise), marital status $(1=$ married; $0=$ otherwise), number of women married 
a reliable amount of rain. The contribution of agricultural production is a result of high amounts of harvest realized in this part of the sub-region. Although Amudat district is located in pastoral zone of the sub-region, contribution own agricultural production to household energy and nutrient requirements was next to that of Abim district. This could be as a result of up to $90 \%$ of the household members engaging in agricultural production (Table 3 ). Own agricultural production contributed to a low extent to household energy and nutrient requirements in Kaabong and least in Moroto (Table 4) possibly as a result of engagements in other livelihood activities such as trade, casual labor, pastoralism, gold mining, firewood sale among others (Table 3 ) which could provide means of access food resources. Similar findings were reported in a study [52] that sought to understand livelihood dynamics in northern Karamoja. The low contribution of household's own agricultural production to their energy and nutrients needs in the current study contradicts a similar study [53] that reported improved energy, zinc and iron outputs to households engaged in agriculture. Authors attribute this disparity to difference in methods and approaches, and agro-ecological condition of Karamoja, being largely semi-arid in nature from which agricultural outputs are insufficient even if they are available. Therefore, Ministry of Agriculture Animal Industries and fisheries (MAAIF) together with other development agencies promoting agriculture should intensify strategies to increase agricultural output beyond just food availability and promote nutrition sensitive agricultural interventions in such a semi-arid environment and pastoral systems. Ministry of Health $(\mathrm{MoH})$ and health affiliated development partners should complement agricultural initiatives by designing appropriate dietary guidelines, followed by capacity building of extension workers and front line health and nutrition practitioners who in turn can be change agents for improving household nutrient intake. This recommendation is consistent with the previous evidence [54] that increased food availability and diversity coupled with nutrition awareness helped the households improve food consumption pattern, move towards meeting the daily RDI, and ensure better nutrient intake.

The current study has contributed to the existing and emerging body of knowledge in that unlike other studies that used dietary diversity [55-57], consumption units [54], nutrition status [6] and several socio economic variables as contributing indicators from agricultural production, this study focused on the energy and nutrient yield from household agricultural production and compared with total energy and nutrient required. The current study also appears to provide a more detailed contribution of household's agricultural output to nutrient requirements than a previous study in Uganda [58] that attempted to measure calorie intake but largely used dietary diversity and food consumption scores in assessing the influence of farming systems on dietary diversity and farming systems. Herein, scholars, government and development agencies can extrapolate from this study to steer and bolster household agriculture and nutrition initiatives in semi-arid areas and areas with areas with highly variable and uncertain climate conditions.

The result further demonstrated variations in the households' ability to meet energy and nutrient requirements, (Figs. 2, 3, 4) which is a reflection of their agricultural production levels. The variations in the production level could be attributed to the different agro-ecological zones $[59,60]$ that the districts occupy, driving the livelihood activities of households such as brewing, firewood sale, gold mining charcoal burning and sale as well as other forms of business and demographic factors (Table 3). The variations in the pattern of intake of energy and nutrients could also be attributed to differing food consumption patterns and differences in the relative availability of specific classes of foods [61] as well as the composition of the household (Table 3). The current study also concurs with the previous study [53] that the ability of family farming to provide households with their basic nutritional needs varies widely among households on account of household-level cropping area and household size. These findings point out an important insight because dietary intake of agricultural households largely depends on food supplies from their own farm [46]. However, the evidence for attaining dietary supplies from own-farm was not conclusive for the impact of own supply on livestock based food consumption [46]. Amidst multifaceted causes of food and nutrition security [8, $62,63]$, the inability of the households in Karamoja subregion to meet daily energy and nutrient requirement from own agricultural production is manifested in a glaring persistence in poor food and nutrition status in the sub-region. As such, an understanding of the relationship between household or individual-level food insecurity and dietary adequacy is imperative in appraising the consequences of food insecurity for nutritional health and well-being [61]. Inadequate dietary intake is one of the immediate causes of malnutrition $[64,65]$. Owing to the fact that in the present study, dietary intake from agricultural production in Karamoja is inadequate, malnutrition among the household members can be worsened by extreme shocks in weather conditions. This scenario can also pose a critical public health challenge in Karamoja sub-region through the relationship of malnutrition with disease pathways [66-69]. Women, (especially pregnant and lactating women), infants and young children are among the most nutritionally vulnerable groups 
$[1,70]$ because of their high physiological requirements [4]. Therefore, poor nutrition among such groups if not addressed can have both short-term and long-term health outcomes, among which are; low birth weight, low maternal weight, poor cognitive development, increases non-communicable disease prevalence, healthcare costs, and disease burden; and negatively impacts economic and human productivity [71-73].

It is worth noting that the contribution of own production did not account for energy and nutrients derived from animal sources, which is a potential limitation to the current study. Further, the estimates of the contribution of energy and nutrients were based on harvests from agricultural production but not actual quantities of foods consumed by each household member. The estimates of the contribution also omitted crops harvested and consumed in piecemeal such as leafy vegetables and roots and tubers due to lack of appropriate methods for estimating their product in levels. Hence, the results could have reflected over or under reporting of energy and nutrient levels from agricultural production.

It is generally being reported that socio-economic and demographic factors influence agricultural production in different ways. Age and marital status were not significant predictors to energy and nutrient intake from agricultural production (Table 6). These contradict previous studies that reported age as positive and significant factor in the farmer's output levels on account of accumulated farming experience [74], which could translate to adequate diet. Marital Status was also reported to have positive relationship with the farmer's output levels [74, 75]. The result (Table 6) further indicates that being in polygamous family increased the supply of iron to the household from agricultural production by 0.112 . This is tends to agree with previous studies $[76,77]$ polygamy has a net positive effect on agricultural outputs. This does not rule out the benefit of increased food availability and diversity and ultimately, quality diets. However, Damon and McCarthy [38] argued that polygamous unions may either create resource competition between wives and worsen an inefficient intra-household distribution of inputs negatively influencing agricultural outputs or improve agricultural outcomes through Pareto efficient cooperation among household members. Such contradictions have also been reported in other studies [76, 78]. This suggests that agricultural outputs from polygamous families are context specific and thus the situation in Karamoja sub-region may limitedly apply to other communities. On the other hand, subsistence farming in which most of the women (spouses) were occupied in increased supplies of energy and nutrients to the household and also household energy requirement. This is in agreement with several studies [38-40] that place women's role in agriculture as key factor in household food security and dietary intake on account of their significant productivity. In this regard, policies and interventions should support this contribution to improve household dietary intake in Karamoja sub-region and possibly in other communities. Lack of formal education among the household heads negatively influenced energy and nutrient supplied from household agricultural production as well as energy required by the households (Table 6). This concurs with several studies that reported that education positively influenced the level of cassava production [75]. Another study [74] also posited that a year increase in educational qualification brings about an increase in farmers output by $50.8 \mathrm{~kg}$. Authors agree with the assertion [38, 77] that educated farmers are able to assimilate information on improved methods of farming with ease. In the current study, lack of formal education among the women (spouses) increased protein and zinc requirements of the household. This suggests that low education level predisposes the women in Karamoja sub-region to nutritional deficiencies. In fact with exception of Abim, majority of the inhabitants never attained any formal education and therefore are illiterate (Table 3). The result (Table 6) further shows that increase in household size by one person increases household protein, iron and zinc requirements by $0.098,0.116$ and 0.111 , respectively. This is obvious because additional member to the households creates additional burden on the household food resources. The finding agrees with a previous study reporting that food available to larger families per head was frequently lower than that available to smaller families and that per capita food intake decreases with an increase in family size. This could be worsened as a previous study reported an inverse relationship indicating that as the household size increases by one person, farmers output levels decrease in crop yield [74], especially when there is lack of support from that member of the household to agricultural production.

\section{Conclusion}

The purpose of the current study was to examine the contribution of own agricultural production to energy and nutrient requirement based on the recommended daily allowance. The total energy and nutrient energy and nutrient required by the household was compared with energy and nutrients supplied by own agricultural production. Therefore, this study provides a significant contribution to understanding the extent to which households in Karamoja sub-region achieve energy and nutrient intake from their own agricultural production. Generally, own agricultural production contributes limitedly to household energy and nutrient needs in the sub-region. Therefore, this study has demonstrated that 
majority of the household in Karamoja sub-region are unable to meet energy and nutrient needs from agricultural production. The study also has shown that household energy and nutrients required was much higher than that own agricultural production supplies.

The study further demonstrated great variations in the households' capacity to derive energy and nutrition nutrients from own agricultural produce in Karamoja sub-region. Being in Polygamy positively predicted iron supplied from agricultural production while subsistence farming by spouse positive predicted energy required and energy and nutrients supplied by the household own agricultural production. On the other hand, lack of formal education among the spouse positively predicted protein and iron required by the household from own agricultural production. Lack of formal education among the household heads negatively predicted energy required by the household, and energy and nutrients supplied from own agricultural production. Protein, iron and zinc required by the household increased with additional household member to the household.

The current study provides three important insights to scholars: first, appropriate models need to be studied to ascertain the contribution of other livelihood options to food and nutrition security. Second, future studies also need to focus on the other pillars of food security, for example, food utilization its effect on food and nutrition security. Lastly third, studies on interventions that enrich nutrient content of the locally available foods can contribute to efforts towards addressing food and nutrition security especially among women and children.

\section{Acknowledgements}

Professor Martina Hennesy of Trinity College Dublin, and Professor Nazarious Mbona of Makerere University, the Principle Investigator and the country coordinator of the NOURISH project, respectively, and Professor J.H Nyeko Pen-Mogi, the Principle Investigator of Work Package 2 of the NOURISH project at Gulu University.

\section{Authors' contributions}

CM: conception and design, data collection, analysis and interpretation, drafting of the manuscript. MB: critical revision of the draft manuscript IO-U: critical review of the draft manuscript. ANK: critical review of the draft manuscript. DT: critical review of the draft manuscript. DO: conception and design, critical review and final approval of the draft manuscript for publication. All authors read and approved the final manuscript.

\section{Funding}

This research was funded by the Irish Aid and Higher Education Authority (HEA) under the Programme of Strategic Cooperation between Irish Aid and Higher Education and Research Institutes 2007-2011 through the NOURISH Project.

\section{Availability of data and materials stake}

The datasets used and/or analyzed during the current study are available from the corresponding author on reasonable request.

\section{Declarations}

Ethics approval and consent to participate

Clearance and registration of the research work reported in this dissertation was provided by Uganda National Council of Science and Technology (UNCST) and the permission to conduct the study was granted by the Resident District Commissioners (RDC) of the respective districts. Verbal consent was obtained from participants before their enrollment into the study.

\section{Consent for publication}

Not applicable.

\section{Competing interests}

The authors hereby declare no competing interest interests.

\section{Author details}

${ }^{1}$ Department of Food Science and Postharvest Technology, Faculty of Agriculture and Environment, Gulu University, P.O. Box 166, Gulu, Uganda. ${ }^{2}$ Department of Rural Development and Agribusiness, Faculty of Agriculture and Environment, Gulu University, P.O. Box 166, Gulu, Uganda. ${ }^{3}$ Department of Food Technology \& Nutrition, School of Food Science, Nutrition and Bio-Science Engineering, College of Agricultural and Environmental Sciences, Makerere University, P.O. Box 7062, Kampala, Uganda. ${ }^{4}$ Department of Geography, Faculty of Arts and Social Sciences, National University of Singapore, Singapore, Singapore.

Received: 27 July 2021 Accepted: 23 December 2021

Published online: 15 January 2022

\section{References}

1. G Rasul A Hussain B Mahapatra N Dangol 2017 Food and nutrition security in the Hindu Kush-Himalayan Region J Sci Food Agric https://doi.org/ 10.1002/jsfa. 8530

2. S Lemke AC Bellows 2011 Bridging nutrition and agriculture local foodlivelihood systems and food governance integrating a gender perspective Technol Assess 2025260

3. Fanzo J, Lachat C, Sparling T, Olds T. The nutrition sensitivity of agriculture and food policies: a summary of eight country case studies. In: SCN News Changing Food Systems for Better Nutrition. United Nations System Standing Committee on Nutrition (UNSCN). 2013; UNSCN No. 40 2013: ISSN 1564-3743. http://www.unscn.org/files/Publicatio. Accessed July 2020

4. D Mosha CR Canavan AL Bellows MM Blakstad RA Noor H Masanja J Kinabo W Fawzi 2018 The impact of integrated nutrition-sensitive interventions on nutrition and health of children and women in rural Tanzania: study protocol for a cluster-randomized controlled trial BMC Nutr 429

5. J Fanzo S Curran R Remans V Mara JS Briseño D Cisewski G Denning P Fracassi 2014 Simulating potential of nutrition-sensitive investments. Center for Globalization and Sustainable Development The Earth Institute, Columbia University New York

6. MG Wordofa M Sassi 2020 Impact of agricultural interventions on food and nutrition security in Ethiopia: uncovering pathways linking agriculture to improved nutrition Cogent Food Agric https://doi.org/10.1080/ 23311932.2020.1724386

7. Sumelius J, Bäckman S, Kahiluoto H, Rötter R, Nyairo N, Parviainen T, Islam ZKM, Hossain M, Tenaw S. Climate change: agriculture, food security and human health How can sustainable agricultural systems promote food security in a changing climate? 9th European IFSA Symposium, Vienna (Austria); 2010.

8. Food and Agriculture Organization (FAO). The role of agriculture and rural development in achieving SDG 1.1; Paper for presentation at the United nations expert group meeting on eradicating rural poverty to implement the 2030 Agenda for sustainable development, UNECACC-AA, FAO, Italy, Rome; 2019.

9. United Nations Development Programme (UNDP). Africa Human Development, Towards a Food Secure Future United Nations Development 
Programme Regional Bureau for Africa (RBA) 1 UN Plaza, New York, USA; 2012.

10. Moyo S. Family farming in sub-Saharan Africa: its contribution to agriculture, food security and rural development. Working Paper. 2016; No. 150. International Policy Centre for Inclusive Growth (IPC-IG), Brasilia

11. International Fund for Agricultural Development (IFAD) and United Nations Environmental Programme (UNEP). (2013) Smallholders, food security, and the environment. 2013; IFAD, Rome, Italy.

12. II Berchin NA Nunes WS Amorim de GAA Zimmer FR Silva da VH Fornasari M Sima JBSO Andrade-Guerra de 2019 The contributions of public policies for strengthening family farming and increasing food security: the case of Brazil Land Use Policy 82573584

13. IT Abdelhedi SZ Zouari 2018 Agriculture and food security in North Africa: a theoretical and empirical approach J Knowl Econ https://doi.org/10. 1007/s13132-018-0528-y

14. DD Mengistu Degaga DTand Tsehay AS. 2021 Analyzing the contribution of crop diversification in improving household food security among wheat dominated rural households in Sinana District, Bale Zone Ethiopia. Agric Food Secur. 107 https://doi.org/10.1186/s40066-020-00280-8

15. LL Maliwichi SA Oni OS Obadire 2012 An investigation into the factors affecting food availability, choices and nutritional adequacy of smallholder farming households under irrigation and dryland farming in Vhembe district of Limpopo, province, South Africa Afr J Agric Res 725 36533664 https://doi.org/10.5897//AJAR11.1062

16. United Nations (UN). Transforming our world: the 2030 Agenda for Sustainable Development, General Assembly, Seventieth session; 2015

17. Gollin D, Rogerson R. Agriculture, roads and economic development in Uganda. Department of Economics, Arizona State University; 2010.

18. Uganda Bureau of Statistics (UBOS) and Ministry of Agriculture, Animal Industry and Fisheries (MAAIF). Uganda Census of Agriculture 2008/2009, Volume IV: Crop Area and Production Report, Entebbe, Uganda; 2010

19. Food and Agriculture Organization (FAO). Nutrition Country Profile of the Republic of Uganda. Uganda Nutrition Profile-Nutrition and Consumer Protection Division, FAO, Italy, Rome; 2010.

20. Ministry of Agriculture, Animal Industry and Fisheries (MAAIF). Agricultural Sector Performance Review Report Financial Year 2016/2017, Entebbe, Uganda; 2017.

21. Ministry of Agriculture, Animal Industry \& Fisheries (MAAIF). Agriculture for Food and Income Security Agriculture, Sector Development Strategy and Investment Plan: 2010/11-2014-15, MAAIF, Entebbe, Uganda; 2010.

22. Sangeetha M, Bayite-Kasule S, Mugarura S. Enterprise Budget Survey: An Analysis of Crop and Livestock Enterprises. Uganda Strategy Support Program (USSP), Working Paper No. 5, International Food Policy Research Institute; 2010.

23. Bategeka L, Kiiza J, Kasirye I. Institutional Constraints to Agriculture Development in Uganda. Research Series. 2013; No. 101: Economic Policy Research Centre (EPRC).

24. United Nations Children's Fund (UNICEF). Food and Agriculture Organization (FAO) and World Food Programme (WFP), Food Security and Nutrition Assessment in Karamoja Sub-Region, Uganda; 2017.

25. GE Edame AB Ekpenyong WM Fonta EJC Duru 2011 Climate change, food security and agricultural productivity in Africa: issues and policy directions Int J Human Soc Sci 121205223

26. Schniepper N. Dryland commodities and livelihoods in Karamoja Fairventures worldwide FVW, Stuttgart, Germany; 2013.

27. C Nakalembe J Dempewolf C Justice 2017 Agricultural land use change in Karamoja Region, Uganda Land Use Policy 62212

28. Cullis A. Agricultural Development in Karamoja, Uganda: recent trends in Livestock and crop systems, and resilience impacts. Karamoja Resilience Support Unit, USAID/Uganda, UK aid, and Irish Aid, Kampala; 2018.

29. Ayoki M. Pastoral and Agro-Pastoral Livelihoods tn the Greater Horn of Africa: Food Security and Livelihood Trends in Karamoja. Institute of Policy Research and Analysis; 2007.

30. Egeru A, MacOpiyo RL, Mburu J, Majaliwa MGJ, Aleper D. Trends in climate variation in Karamoja sub-region, northern eastern Uganda, Fourth RUFURUM Biennial Regional Conference 21-25 July 2014, Maputo, Mozambique. Research application summary; 2014, p. 449-456.

31. Lazzaroni S. Climate Change, Weather Variability and Food Consumption: A Multidisciplinary Study of Rural Uganda, Department of Economics and Social Sciences Catholic University of the Sacred Heart, Piacenza, Italy; 2013
32. D Hedeker RD Gibbons C Waternaux 1999 Sample size estimation for longitudinal designs with attrition J Educ Behav Stat 247093

33. C Muggaga D Ongeng B Mugonola I Okello-Uma NA Kaaya D Taylor 2017 Influence of sociocultural practices on food and nutrition security in Karamoja Sub-region of Uganda Ecol Food Nutr 565424447

34. Hotz C, Lubowa A, Sison C, Moursi M, Loechl C. A Food composition table for Central and Eastern Uganda, Harvest Plus Technical Monograph 9; Washington, D.C and Cali: International Food Policy Research Institute (IFPRI) and International Center for Tropical Agriculture (CIAT); 2012.

35. Food and Agriculture Organization (FAO). World Health Organization (WHO) and United Nations University (UNU), Human energy requirements, Joint FAO/WHO/UNU Expert Consultation, Italy, Rome; 2001.

36. Summary of tables: Dietary Reference Intakes-Estimated Average requirements. www.nal.usda.gov. Accessed 16 Oct 2018.

37. Action Against Hunger and Institute of International and Strategic Relations (Institut de relations internationales et strategies (iRiS). Future Livelihoods in Karamoja, A Scenario Analysis Looking Forward to 2022 East Africa; 2017.

38. AL Damon AS McCarthy 2019 Partnerships and production: agriculture and polygyny in Tanzanian households Agric Econ https://doi.org/10. 1111/agec.12507

39. Ransom E, Wright W, and Bain C. Female farming systems. sociology and anthropology faculty publications. 2016; 52. http://scholarship.richmond. edu/socanth-faculty-publications/52. Accessed Nov 2021.

40. McKenna KA. The role of Ugandan women in rural agriculture and food security. Electronic Theses and Dissertations. 2014; 420. https://digitalcom mons.du.edu/etd/420. Accessed Oct 2021.

41. IA Wright STarawali M Blümmel B Gerard N Teufel M Herrero 2012 Integrating crops and livestock in subtropical agricultural systems J Sci Food Agric 9210101015

42. L Toma AP Barnes LA Sutherland S Thomson F Burnett K Mathews 2018 Impact of information transfer on farmers' uptake of innovative crop technologies: a structural equation model applied to survey data J Technol Transf 43864881 https://doi.org/10.1007/s10961-016-9520-5

43. Ferreira T. Does education enhance productivity in smallholder agriculture? Causal evidence from Malawi. Stellenbosch Economic Working Papers. 2018; WP05/2018 (www.ekon.sun.ac.za/wpapers/2018/wp052 018March2018). Accessed Nov 2021.

44. LK Ninh 2021 Economic role of education in agriculture: evidence from rural Vietnam J Econ Dev 2314758 https://doi.org/10.1108/ JED-05-2020-0052

45. Department for International Development (DFID) of United Kingdom. Scaling Up Nutrition; UKs position Paper on Undernutrition, Department for International Development, UK London; 2011.

46. VL Pandey SM Dev U Jayachandran 2016 Impact of agricultural interventions on the nutritional status in South Asia: a review Food Policy 6228 40

47. D Akwango BB Obaa N Turyahabwe Y Baguma A Egeru 2017 Effect of drought early warning system on household food security in Karamoja sub-region, Uganda Agric Food Secur 643

48. World Food Programme (WFP) and United Nations Children's Fund (UNICEF). Food security and nutrition assessment in Karamoja Region, School of Public Health Makerere University College of Health Sciences \& WFP Analysis, Monitoring \& Evaluation (AME) Unit, Kampala, Uganda; 2016.

49. Action Against Hunger. Nutrition surveillance data analysis of Karamoja (December 2009-May 2012), Uganda, ACF International; 2013.

50. Gelsdorf K, Maxwell D, Mazuran D. Livelihoods basic services and social protection in Northern Uganda and Karamoja; Secure Livelihoods Research Consortium (SLRC)-Overseas/Development Institute (ODI) London, United Kingdom Working Paper 2012; 4: 6-7

51. United States Agency for International Development (USAID). Climate change and conflict in Uganda: The cattle corridor and Karamoja. USAID: Washington DC; 2011.

52. Burns J, Bekele G. Livelihood Dynamics in Northern Karamoja, Feinstein International Center; 2013.

53. A Arce H Creed-Kanashiro M Scurrah R Ccanto E Olivera D Burra S Haan De 2016 The challenge of achieving basal energy, iron and zinc provision for home consumption through family farming in the Andes: a comparison of coverage through contemporary production systems and selected 
agricultural interventions Agric Food Secur 523 https://doi.org/10.1186/ s40066-016-0071-7

54. A Pradhan R Raju DJ Nithya AK Panda RD Wagh MR Maske 2021 Farming system for nutrition-a pathway to dietary diversity: evidence from India PLoS ONE 163 e0248698 https://doi.org/10.1371/journal.pone.0248698

55. S Koppmair M Kassie M Qaim 2016 Farm production, market access and dietary diversity in Malawi Public Health Nutr 202325335

56. LD Kissoly SK Karki U Grote 2020 Diversity in farm production and household diets: comparing evidence from smallholders in Kenya and Tanzania Front Sustain Food Syst 477 https://doi.org/10.3389/fsufs.2020.00077

57. E Kiptoo LM Waswa Ol Ayuya 2021 Linking farm production to household diets: evidence from two low potential areas in Kenya Cogent Food Agric 711913842 https://doi.org/10.1080/23311932.2021.1913842

58. Linderhof V, Powella J, Vignes R, Rubena R. The influence of household farming systems on dietary diversity and caloric intake: the case of Uganda. Paper presented at the 5th conference of the African Association of Agricultural Economist, 23-26 September 2016, Addis Ababa (Ethiopia)

59. United States Agency for International Development (USAID). Karamoja Region Food Security Assessment: Uganda, The Famine Early Warning System Network (FEWS Net); 2010.

60. Adoch C, Ssemakula E. Killing the Goose that lays the golden egg: an analysis of budget allocations and revenue from the environment and natural resource sector in Karamoja Region. ACODE Policy Research Series. 2011; No. 47, Kampala, Uganda.

61. VS Tarasuk GH Beaton 1999 Household food insecurity and hunger among families using food banks Can J Public Health 90109113

62. Okello B, Immink M, Mischler F. Integrating food and nutrition security and the right to food in local government development planning and budgeting, FAO; 2013

63. H El-Bilali C Callenius C Strassner L Probst 2019 Food and nutrition security and sustainability transitions in food systems Food Energy Secur 8 e00154 https://doi.org/10.1002/fes3.154

64. Blössner M, de Onis M. Malnutrition: quantifying the health impact at national and local levels. WHO Environmental Burden of Disease Series No. 12, World Health Organization, Geneva; 2005.

65. United Nations Children's Fund (UNICEF). UNICEF's approach to scaling up nutrition for mothers and their children, Discussion paper. Programme Division, UNICEF, New York; 2015.

66. A Chiabi B Obadeyi FD Nquefack RM Chiabi EN Berinyuy EN Chiabi TA Mbang MT Obama 2018 The vicious cycle of malnutrition and childhood infections—what are the policy implications? Arch Pediatr Neonatol 11 2125

67. JL Walson JA Berkley 2018 The impact of malnutrition on childhood infections Curr Opin Infect Dis 313231236

68. Folaranmi T. Food insecurity and malnutrition in Africa: current trends, causes and consequences. Consultancy Africa; Intelligence's Public Health Unit; 2012

69. World Health Organization (WHO). Global health risks; mortality and burden of disease attributable to selected major risks, Geneva: WHO; 2009.

70. A Lartey 2008 Maternal and child nutrition in Sub-Saharan Africa: challenges and interventions Proc Nutr Soc 67105108

71. I Cetin A Laoreti 2015 The importance of maternal nutrition for health J Pediatr Neonatal Individual Med 42 e040220

72. A Devine T Lawlis 2019 Nutrition and vulnerable groups Nutrients 11 1066

73. S Ghosh K Spielman M Kershaw K Ayele Y Kidane K Zillmer L Wentworth A Pokharel JK Griffiths T Belachew E Kennedy 2019 Nutrition-specific and nutrition-sensitive factors associated with mid-upper arm circumference as a measure of nutritional status in pregnant Ethiopian women: Implications for programming in the first 1000 days PLoS ONE 143 e0214358

74. TU Anigbogu OE Agbasi IM Okoli 2015 Socio-economic factors influencing agricultural production among cooperative farmers in Anambra State, Nigeria Int J Acad Res Econ Manage Sci https://doi.org/10.6007/ IJAREMS/V4-i3/1876

75. MM Abdul-kareem MA Sahinli 2018 Demographic and socio-economic characteristics of cassava farmers influencing output levels in the Savannah Zone of Northern Ghana Afr J Agric Res 134189195

76. Akresh R, Chen JJ, Moore C. Altruism, Cooperation, and Efficiency: Agricultural Production in Polygymous Households. Discussion Paper. 2011
No. 6265. Forschungsinstitut zur Zukunft der Arbeit Institute for the Study of Labor

77. HB Jacoby 1995 The economics of polygamy in Sub-Saharan Africa: female productivity and the demand for wives in Côte d'Ivoire J Polit Econ 1035938971

78. M Hidrobo JB Hoel W Katie 2021 Efficiency and status in polygamous pastoralist households J Dev Stud 572326342 https://doi.org/10.1080/ 00220388.2020 .1762863

\section{Publisher's Note}

Springer Nature remains neutral with regard to jurisdictional claims in published maps and institutional affiliations.
Ready to submit your research? Choose BMC and benefit from:

- fast, convenient online submission

- thorough peer review by experienced researchers in your field

- rapid publication on acceptance

- support for research data, including large and complex data types

- gold Open Access which fosters wider collaboration and increased citations

- maximum visibility for your research: over $100 \mathrm{M}$ website views per year

At BMC, research is always in progress.

Learn more biomedcentral.com/submissions 